\title{
Matrix Attachment Region
}

National Cancer Institute

\section{Source}

National Cancer Institute. Matrix Attachment Region. NCI Thesaurus. Code C13437.

Regions of chromosomal DNA attached to a structural component of the interphase

nucleus termed the nuclear matrix, permitting the partitioning of DNA in the

chromosomes into looped chromatin domains. 